УДК 1: 82-92

DOI: $10.32837 /$ apfs.v0i25.877

Назип Віленович Хамітов

доктор філософських наук, професор,

провідний науковий співробітник

Інститут філософії імені Г. Сковороди НАН України, м. Київ, Україна

Світлана Анатоліївна Крилова

доктор філософських наук, професор

завідувач кафедри культурології та філософської антропології

НПУ імені М. Драгоманова, м. Київ, Україна

\title{
ФЕНОМЕН ФІЛОСОФСЬКОЇ ПУБЛІЦИСТИКИ ТА СОЦІОКУЛЬТУРНА ВІДКРИТІСТЬ АКАДЕМІЧНОЇ ОСВІТИ І НАУКИ
}

\begin{abstract}
Анотація. Осмислюється філософська публіцистика та іï суспільна відкритість в академічній освіті і науці. Автори обгрунтовують тезу про суттєву різницю ступеню відкритості академічного знання у авторитарному i демократичному суспільстві. У тоталітарному й авторитарному суспільстві логіка і міра суспільної відкритості академічного знання вирішується закритою групою осіб. У демократичному суспільстві академічна відкритість можлива лише у публічній дискусії, живому просторі дискурсу, який 3 необхідністю виходить за межі академічної спільноти.

Обгрунтовано, що в результаті дії філософської публіцистики маємо справжню тут-ітепер-відкритість академічного знання в його освітніх і наукових вимірах, відкритість сучасності.

Філософська публіцистика - не просто доступне подання історії філософії або сучасного стану напрямків теоретичної філософії, це сфера духовної творчості, в якій вічні світоглядні проблеми постають у актуальному суспільному контексті. Показана специфіка філософської публіцистики відносно споріднених жанрів есеїстки і журналістики. Філософська публіцистика в своїй глибині завжди є гуманістичною, вона стоїть на сторожі свободи думки, пробуджує їі критичність, захищає від маніпуляцій. Обгрунтована теза про консолідуючий характер філософської публіцистики в сучасних кризових суспільствах, зокрема в Україні. Показано тяжіння справжнього академізму до публіцистичності. Справжній академізм іманентно тяжіє не стільки до публічності, скільки до nубліцистичності - чим вищий академічний статус освітянина та науковця, тим більшої міри публіцистичності він вимагає - міри відкритості текстів та виступів, здатності говорити доступно і цікаво, щоб бути почутим колегами сусідніх галузей знання і всім суспільством. Ця публіцистичність є саме філософською, адже дає можливість своєму носію інтегрувати, генерувати й креативно захищати ідеї на різних публічних майданчиках.

Автори вводять поняття «академічна філософська публіцистика»; в результаті дії такої публіцистики в сучасному демократичному суспільстві виникає відкритість освіти і науки.
\end{abstract}

Ключові слова: публічність, публіцистика, філософська публіцистика, академічна філософська публіцистика, філософська есеїстика, філософське мистецтво, буденне буття людини, граничне буття людини, метаантропологія.

У межах професійної спільноти i за іï межами академічна освіта i наука набувають практичного й суспільного звучання. Саме у другій своїй іпостасі освіта і наука здатні створювати у суспільстві спільний ціннісний і когнітивний, більше того, світоглядний простір.

Виникає питання: як академічна освіта і наука можуть набувати статус суспільної відкритості, коли філософія, фізика, математика, філологія, історія, соціологія існують не для філософів, фізиків, математиків, істориків, філологів, соціологів, а для всього народу, нації, країни? У тоталітарному й авторитарному суспільстві логіка і міра суспільної відкритості академічного знання вирішується закритою групою осіб. У 
демократичному суспільстві - академічна відкритість можлива лише у публічній дискусії, живому просторі дискурсу, який з необхідністю виходить за межі академічної спільноти.

Можна припустити, що це відбувається тоді, коли і освіта, і наука виявляються, обговорюються, розгортаються у формі публіиистики. Проте мова іде передусім про філософську публіцистику, яка здатна як інтегрувати академічне знання, так i поширювати його у суспільстві, здатна «узагальнювати спільні цінності й генерувати сенси» $[12$, с. 376$]$.

В результаті дії філософської публіцистики маємо справжню тут-і-тепервідкритість академічного знання в його освітніх і наукових вимірах, відкритість сучасності, адже така публіцистика, на відміну від освіти чи науки «реалізується тут i тепер і дає результат, що необхідний вже сьогодні» [12, с. 377].

Але наш опонент може сказати, що в даному контексті слід говорити не про філософську, а про академічну публіцистику, яка і здатна «обслуговувати» освіту i науку (пропагувати, популяризувати, практично спрямовувати тощо). I додасть: філософська публіцистика значною мірою виходить за межі академічної форми як у своїй генезі, так і у предметності. Можна відповісти таке: очевидно, що академічна публіцистика може існувати, і це важлива галузь публіцистики, але вона може бути занадто зашореною і обмеженою власне академічною формою іiі нинішніх межах, занадто залежною від завдання «популяризації». Тоді як філософська публіцистика здатна виходити на рівень метапозиції, що дозволяє побачити й розв'язати проблемні вузли як у питаннях відчуженості академічного життя від суспільства, так і самого академічного життя. В понятті «філософська публіцистика» звучить та сама свобода думки і духу, яка промовляє і в науковому ступені «доктор філософії».

I тут не можна оминути критичне запитання нового опонента. Коли ми говоримо про філософську публіцистику в контексті освіти і науки, розділяючи ці дві гілки академізму, то наскільки актуальне таке поняття? Може продуктивніше використовувати поняття «освітня публіцистика» та «наукова публіцистика», тоді як філософська публіцистика є чи занадто широкою чи занадто вузькою за змістом? На перший погляд, це начебто так. Але наукова публіцистика і освітня публіцистика замкнені кожна на своїй сфері, тяжіють до популяризаторства в кожній з них, тоді як у філософської публіцистики є гуманістична й креативна широта, в академічних виявах якої маємо «волю до наукової новизни» [13], що в межах проекту метаантропології [8; $11 ; 12 ; 20]$ може бути потрактована як така, що виводить з буденного в граничне буття людини [11; 12].

Справжній академізм іманентно тяжіє не стільки до публічності, скільки до nублічистичності - чим вищий академічний статус освітянина та науковця, тим більшої міри публіцистичності він вимагає - міри відкритості текстів та виступів, здатності говорити доступно і цікаво, щоб бути почутим колегами сусідніх галузей знання і всім суспільством. На нашу думку, ця публіцистичність є саме філософською, адже дає можливість своєму носію інтегрувати, генерувати й креативно захищати ідеї на різних публічних майданчиках.

Можна припустити, що найбільшою мірою філософська публіцистика проявляється в гуманітарному (соціогуманітарному) знанні. Можна сказати, що вона виростає з гуманітарного знання. В свою чергу, завдяки філософській публіцистиці гуманітарна освіта і наука набувають такої суспільної відкритості, що стають власне гуманітаристикою - сферою практичного поширення знань і практик людяності.

I знов виникає критичне запитання нового опонента. Може, філософська публіцистика стосується не науки і освіти взагалі і не гуманітарної освіти і науки зокрема, а лише філософської освіти $i$ науки? Чи не зводимо ми академізм і 
гуманітаристику до філософії? I у конкретному випадку гуманітарної освіти і науки може слід говорити про гуманітарну публіцистику? Відповідь на це питання передусім потребує усвідомлення того, що гуманітарна публіцистика значною мірою $\epsilon$ синонімом публіцистики як такої. Справжня публіцистика завжди людиновимірна й людиноцентрична, так само як справжня наука й освіта $[1 ; 2 ; 4]$, а тому гуманітарна за своєю природою. Проте цієї гуманітарності недостатньо для вирішення тих питань, що стоять перед сучасною освітою і наукою, в тому числі гуманітарною. Потрібна філософська публіцистика, яка тисячоліттями (у культурі Заходу як мінімум від Сократа) культивувала й накопичувала креативні й несподівані рухи думки у рішенні проблемних питань буття людини. Отже, філософська публіцистика $є$ поглибленням просто публіцистики до усвідомлення вічних питань і вічних суперечностей людського буття. I це усвідомлення виражається таким чином, що входить в актуальний контекст свого народу і його країни у будь-які епохи, консолідуючи на цивілізаційні звершення, в тому числі в освітній і науковій сферах.

Ми є свідками консолідуючого характеру філософської публіцистики в сучасних кризових суспільствах, до яких належить і Україна. I це не просто консолідація соціуму заради інтересів тієї чи іншої владної групи, це гуманістична консолідація, консолідація задля людини, iї прав, свобод, гідності [6]. Дійсно, «на відміну від журналістики чи просто публіцистики, які заради рейтингу свідомо чи підсвідомо деконсолідують суспільство, «граючи» на конфліктах та скандалах й маніпулюючи свідомістю, філософська публіцистика ставить екзистенціально-психологічні та світоглядні питання, що глибинно хвилюють людину - питання самотності, відчуження, свободи, гідності, справжньої справедливості та ії імітацій, а тому дійсно об'єднує людей навколо гуманістичних цінностей» [12, с. 377].

Надзвичайно важливо усвідомити, що філософська публіцистика - це не просто доступне подання історії філософії або сучасного стану напрямків теоретичної філософії. Філософська публіцистика - це сфера духовної творчості, в якій вічні світоглядні проблеми постають у актуальному суспільному контексті. «Постановка, розв'язання й відкрите дискусійне обговорення цих проблем - це і $є$ реально працюючий у демократичному суспільстві механізм консолідації» [12, с. 377].

Філософська публіцистика в своїй глибині завжди є гуманістичною, вона стоїть на сторожі свободи думки, пробуджує іï критичність, захищає від маніпуляцій. «Філософська публіцистика відрізняється від просто публіцистики i, тим більше, від політичної публіцистики не лише глибиною, а й щирістю подачі, налаштованістю на актуалізацію особистості, а не на маніпуляцію нею, на звільнення думки і дії» [12, с. 377]. Філософська публіцистика - це така смислова відкритість Іншому, яка породжує «красу стосунків» із ним [5].

Але як відрізнити публіцистику від філософської публіцистики в реальному суспільному процесі? Публіцистика притягується до «злоби дня», як магніт. Але вона може посилювати цю злобу, а може звільняти від неї. Саме тоді вона стає філософською публіцистикою. Якщо публіцистика на злобу дня лише посилює злобу дня, то іiі точно не можна назвати філософською публіцистикою. Напевно, краще взагалі обійтися без такої публіцистики.

Філософська публіцистика потребує граничного зусилля духу, вона не дається авторові раз і назавжди. Цікаво, що в історії філософської думки можемо знайти авторів, які були справжніми філософськими публіцистами, але й у певних життєвих обставинах втрачали здатність бути ними. Так, Д. Дідро був філософським письменником і філософським публіцистом, який піднімався над злобою дня. Але час від часу перетворювався в просто публіциста, що розчинявся в «злобі дня». А такий 
автор як Е. Фромм все своє творче життя утримувався на гребні хвилі філософської публіцистики і саме в цьому жанрі написав найбільш відомі книги $[9 ; 10]$.

У вітчизняному академізмі $\epsilon$ автори, які зробили гідний внесок у розвиток сучасної української філософської публіцистики і яких ми маємо за честь вважати своїми вчителями. Це, передусім, академік В. Шинкарук, який залишив в своїй творчій спадщині не лише теоретичні, а й філософсько-публіцистичні твори. В цьому річищі креативно працювали і продовжують працювати $\quad$ В. Андрущенко, В. Кремень, С. Кримський, Л. Левчук, В. Малахов, Л. Сохань, В. Табачковський, М. Попович.

Цікаво відзначити, що в умовах зростання інформаційного тиску на людину та поширення соціальних мереж в Інтернеті філософська публіцистика (так само як і політична публіцистика) стає все більш лаконічною, більше того, - афористичною [18].

А тепер усвідомимо, чим філософська публіцистика відрізняється від есеїстики і від власне філософської есеїстики? Спочатку важливо усвідомити відмінність публіцистики і журналістики. Журналістика - це відображення суспільно значущих подій, публіцистика - їх осмислення, «авторський аналіз цих подій» [12, с. 378]. Філософська ж публіцистика - це авторський аналіз причин суспільно важливих подій і осмислення їх наслідків на основі певної світоглядної позиції. Подібне визначення дозволяє усвідомити, чому філософська публіцистика може переживати епохи.

Філософська есеїстика теж здатна переживати епохи. Але що таке есеїстика? Очевидно припустити, що це «загострена присутність автора в тексті, де все обертається навколо його Я, що обумовлює акцент не на поняттях, а на образах, метафорах» [12, с. 378]. Центрованість філософської есеїстики навколо авторського Я, iї просякнутість авторською суб 'єктивністю дозволяє нам осмислити цю есеїстику як антонім публіцистики. Дійсно, публіцистика по своій суті виходить за межі авторського Я, а в есеїстиці будь-яка проблема «стає вторинною по відношенню до представленості в ньому авторського Я» [12, с. 378]. Тому ми придаємо в есеїстиці таке велике значення стилю, який «є мелодика і ритміка присутності автора в тексті» [12, с. 378]. Акцент на стилі і авторській присутності споріднює есеїстику і поезію.

Однак порівняння не просто публіцистики та есеїстики, а власне філософської публіцистики й філософської есеїстики дозволяє подивитися на проблему дещо інакше. На відміну від просто есеїстики, філософська есеїстика - це рівновага акцентів на проблемі і авторській присутності у тексті. Очевидно, що філософська есеїстика i філософська публіцистика досить близькі. У чому ж відмінність? На перший погляд, філософську публіцистику відрізняє від філософської есеїстки виражена суспільна значущість проблеми, що осмислюється. Проте це не є головним і сутнісним. Адже «філософська есеїстика неминуче виходить за межі снобізму і авторського нарцисизму хоча б тому, що вона філософська» [12, с. 379].

Головна відмінність полягає в іншому: філософська есеїстика $\epsilon$ монолог, філософська публіцистика завжди діалогічна.

Можна припустити, що філософська публіцистика визріває, виростає й розгортається 3 філософської есеїстики, поступово наповнюючись діалоговою відкритістю - осмисленою відкритістю Іншому. Автор філософської публіцистики - це есеїст, який має мужність відкритися Іншому, вступити з ним у діалог навколо спільної проблеми. Можна сказати, що в есеїстиці автор пізнає себе, починає любити в собі творчу особистість і ділиться цим з читачем або слухачем. Він перебуває в бутті щирої відкритості себе у тексті. В філософській же публіцистиці автор включає в свій дискурс Іншого, починає шукати розв'язання спільної проблеми разом із ним. При цьому він не лише егоцентрично шукає істину разом із Іншим, а здатний любити Іншого і цінувати співтворчість 3 ним, що породжує здатність до консенсусу, а не лише до компромісу. 
Таким чином, філософську публіцистику можна визначити як «діалогову філософськку есеїстику» [12, с. 379].

Класикою філософської есеїстики є твори Ф. Ніцше, в них маємо загострену монологічність і поетичну вишуканість. Натомість великий філософський публіцист античності Сократ увійшов в історію філософії саме як ведучий діалогів, а великий філософський теоретик Гегель у своєму філософсько-публіцистичному творі «Хто мислить абстрактно?» доволі дотепно моделює діалоги персонажів і полемізує 3 окресленими образами опонентів.

В сучасній освіті і науці велику значущість мають філософські есе 3 нової й незвичної проблематики. Вони образно-метафорично «схоплюють» проблеми і стають основою для майбутніх теоретичних проривів. Філософська есеїстика $\epsilon$ однаково важливою як для освіти, так і для науки, передусім в їх гуманітарних виявах. Однак не менш значущим є перехід від філософської есеїстики до публіцистики, яка здатна поєднати академічну сферу з життям, що ії оточує, зробити іï насправді практичною.

Більше того, володіння філософською публіцистикою - невід'ємна складова культури доктора філософї̈ у будь-якій галузі знання.

Бути людиною у творчому середовищі завжди означає бути автором. Але стаючи автором, завжди треба залишатися людиною. Для того, щоб це відбулося, треба виявляти і мужність, і мудрість.

Але що це означає: будучи автором, залишатися людиною? Передусім можливість виходити за межі лише професійної спільноти і творити те, що потрібне не лише спільноті, а й всьому суспільству. Це така відкритість Іншому, яка і створює філософію у надрах будь-якої професії і будь-якого життя, філософію, яка завжди $є$ публічною. Філософія - це те надзвичайно елітарне явище, яке $є$ при цьому надзвичайно публічним.

Важливим є усвідомлення того, в чому відмінність філософської публіцистики від теорії - і в освітніх, і в наукових їі вимірах: як пізнання вже пізнаного (освіта) й пізнання ще не пізнаного (наука)? На перший погляд, відмінність лише у тому, що публіцистика $\epsilon$ спрощений вираз теорії; вона популяризує теорію ясною мовою. Однак відмінність є складнішою. Публіцистика інколи ставить ті проблеми людського буття, які вислизають від уваги й можливостей теоретика. У публіцистиці маємо метафори поруч 3 поняттями, загострену полемічну спрямованість й екзистенціальну пронизливість. В результаті проблемність людського буття стає дуже випуклою, виразною. Так само випуклими й виразними стають спроби подолати цю проблемність в тексті.

Можна припустити, що справжня філософська публіцистика - ступінь зрілості філософської есеїстки, яка виводить за межі життєвого світу автора у Світ з великої літери. Проте завжди є небезпека вийти з есеїстки не у філософську публіцистику, а у просто публіцистику, знизивши і навіть втративши горіння філософського духу. Саме тому автору слід робити подвійне зусилля - залишаючись есеїстом, наповнювати свою творчість проблематикою, яка по-справжньому потрібна суспільству, здатна зацікавити Іншого й подолати проблеми спільного буття з ним.

Це й потребує особливої мужності. Мужності відкритості Іншому. Проте цей Інший знаходиться поза межами не лише монологу автора, а й, як було сказано, за межами професійної спільноти.

Філософська публіцистика - це філософія не лише для «професійних» філософів. Або інакше - це значною мірою філософія для нефілософів. Це подолання професійного снобізму і особлива відкритість, які можуть викликати проблеми у спілкуванні з колегами. Проте саме через філософську публіцистику i, також, есеїстку філософія відкривається суспільству. В своїй публіцистичній виявленості філософія 
відкривається зрілим і самореалізованим людям різних професій у їх вільному потязі, а не лише студентам, які змушені вивчати філософію - передусім в теоретичних i, на жаль, не завжди живих виявах. Отже, публіцистична відкритість філософії $є$ мовою іiі справжнього, а не формального входження в освіту, науку, взагалі в культуру.

Отже, в філософській публіцистиці є така важлива ознака як креативність; філософська публіцистика не лише популяризує теоретичні досягнення, а й ініціює їх, висуваючи нові їдеї в образно-метафоричних виявах [14], а надалі актуалізує можливості для їх практичного втілення. Тут важливо зрозуміти, що питання про необхідність і можливість філософської публіцистики є вторинним стосовно питання про можливість і необхідність філософського мистецтва - філософствування в образах і метафорах, а не в поняттях і категоріях [15]. Для Шеллінга, на відміну від Гегеля, вищий і органічний для людини спосіб осягнення Абсолюту - мистецтво, а не наука. Ця лінія продовжується в екзистенціалізмі і персоналізмі - Людину як мікрокосм потрібно осягати в есе i романі, не об'єктивуючи. Ця здатність філософської публіцистики осягати людину без обернення ії на досліджуваний об'єкт, яка споріднює iii з філософським мистецтвом, є одним з вимірів іiі гуманізму.

Сказане актуалізує важливе запитання: філософська публіцистика знаходиться в межах академізму чи за його межами? Для відповіді звернемося до суті академізму.

Академізм - це здатність не «вигадувати велосипед» у тій чи іншій сфері творчої діяльності. Це гранична вимогливість до себе у пізнанні і творчості. Можна сказати, що академізм - це справжнє граничне буття пізнання $i$ творчості. Це аргументованість i строгість пізнавально-творчої діяльності за умови опертя на традицію у ній. Академізм - це перехід від повноти пізнання $і$ творення відомого до пізнання $і$ творення невідомого. Або інакше: академізм є здатність вийти до пізнання й творення невідомого при максимальному вивченні попереднього досвіду.

Постає закономірне питання: чи лише в теоретичних формах можливий академізм? Очевидно, що ні. Принаймні, у західній культурі уперто звучать такі словосполучення як академічний живопис, академічна музика, академічний театр. Мова і приховане за нею буття в культурі натякають на те, що академізм можливий не лише у категоріально-понятійній, а й у образній формі. Очевидним буде визнати плюральність академізму в культурі. Більше того, настав час припустити можливість, необхідність і дійсність академічної філософської публіцистики.

Можна припустити, що одним із завдань філософського академізму $\epsilon$ продукування такої публіцистики. Проте як можливий академізм взагалі не лише в теоретичній, а й у образно-художній формі? Якщо філософія $\epsilon$ сферою людського буття в культурі, то позитивна відповідь очевидна. Часи, коли слідом за Гегелем ми припускали виняткову теоретичність філософії, залишилися в минулому. Тим більше, що ми повинні констатувати, що сам Гегель використовує образно-метафоричні когнітивні конструкції навіть в «Науці логіки», і має цілком публіцистичні твори («Хто мислить абстрактно?»). Інша справа, що академізм різних галузей філософії буде вимагати різних форм прояву і різних акцентів. Так, скажімо, академізм у філософії науки буде переважно теоретичним, тоді як у царині етики, естетики він з необхідністю буде наповнюватися метафоричністю й образністю.

Значною мірою це стосується такої галузі гуманітаристики як філософської антропологія, яка досліджує людську природу, ії колізії та межі, здатність особистості в своєму неповторному тілесному, душевному й духовному існуванні впливати на цю природу та навіть змінювати іiі. До речі, рух від есенціалізму до екзистенціалізму у XIX й XX столітті знаменувався і зміною філософської мови - вона все більше ставала образною й метафоричною. Згадаймо творчі надбання Ж.П. Сартра й А. Камю. 
Проблема людини не може бути осягнена суто теоретичними засобами, це осягнення потребує образності - і не лише есеїстки та публіцистики, а й філософського мистецтва - передусім філософської романістики. І.В. Гете, Г. Гессе, Ф. Кафка $\epsilon$ не меншими філософськими антропологами ніж Л. Фейєрбах, М. Шелер чи Г. Плеснер.

До речі у роботах Л. Фейєрбаха маємо виражений есеїстичний і публіцистичний присмак, а в творчості М. Шелера маємо поступове посилення есеїстичних i публіцистичних тенденцій; остання робота засновника філософської антропології у XX столітті - «Філософський світогляд» [19] - це, по суті, філософське есе, більше того, філософсько-публіцистичний твір. На цій основі один 3 авторів даної статті запропонував поняття «філософсько-антропологічне есе» як вираз особливого жанру філософської думки, що знайшло відображення у назві відповідної книги [14].

Отже, якщо академізм в культурі має плюральні прояви, то у значній мірі це стосується саме філософської антропології, яка задає методологічні й світоглядні вектори в сучасній гуманітаристиці.

Діяльність в академічній освіті та науці постійно потребує публікацій - тез, статей, монографій; саме таким чином академічний автор демонструє власну духовну еволюцію, більше того, робить іiі ко-еволюцією 3 Іншим. В тій чи іншій мірі академічний автор є публічною персоною. Філософська публіцистика як вільний та особистісно універсальний спосіб мислення і постає своєрідною кульмінацією цієї публічності, коли здійснюється гранично можлива відкритість Іншому за межами лише професійної спільноти.

Свобода і діалог у висловленні ідей, обранні світоглядних і методологічних орієнтирів - важлива умова плідного розвитку освіти і науки в демократичному суспільстві. Але важливо відрізнити філософську публіцистику від публічної філософії, про яку так багато говорять останнім часом.

Публічна філософія - це філософія, яка знайшла можливість свого поширення й відкритого звучання у суспільстві. Це, наприклад, публічні лекції з історії античної філософії, викладені популярно й цікаво (в аудиторії, в Інтернеті, на радіо, телебаченні тощо). Не заперечуючи необхідності й важливості такого вияву філософії, визнаючи волю до практичності (у високому розумінні слова) його авторів, слід сказати, що для справжньої відкритості філософії публічності недостатньо. Адже в філософській публічності, яка займається інформуванням і просвітою часто-густо недостає діалогу, критичної й зацікавленої відповіді слухача. Вона, по суті, постає спрощеним теоретичним монологом.

Таким чином, значення філософської публіцистики важко переоцінити. Філософська публіцистика - це інша якість філософського дискурсу завдяки актуальності проблем і діалоговій відкритості будь-якій мислячій людині в сучасності незалежно від іiі освіти та спеціальності. Філософська публіцистика, як і філософська есеїстка, робить і суспільство, і людину більш вільними. I тут потрібно набувати досвід не лише майстерності, а й мужності володіння цим жанром. I цей досвід слід глибоко досліджувати. Автори планують і досліджувати, і продовжувати, і передавати його молоді.

\section{СПИСОК ВИКОРИСТАНИХ ДЖЕРЕЛ}

1. Андрущенко В. Освіта в контексті духовної еволюції цивілізації / В.Андрущенко // Вища освіта України, № 2, 2018. - С. 5 - 12.

2. Андрущенко В., Хамітов Н. Філософська освіта і наука як каталізатор цивілізаційного проекту України / В. Андрущенко, Н. Хамітов // Вища освіта України, № 2, 2017. - C. 5 - 17. 
3. Камю А. Творчество и свобода / А Камю. - М.: Радуга, 1990. - 608 с.

4. Кремень $B$ Г. Філософія людиноцентризму в стратегіях освітнього простору / В. Г. Кремень. - К.: Педагогічна думка. $-2009 .-520$ с.

5. Крилова С. Краса людини: особистість, сім'я, суспільство (соціальнофілософський аналіз): [монографія] / С. Крилова. - Ніжин: Аспект-Поліграф, 2011. $344 \mathrm{c}$.

6. Пирожков С.І., Хамітов Н.В. Україна: від штучної та реальної конфронтації до консолідації // Дзеркало тижня, № 28 (324), 22 липня 2017. - С. 4.

7. Сохань Л.В. Искусство жизнетворчества. Предназначение. Жизнетворчество. Судьба / Л.В. Сохань. - К.: Издательский Дом Дмитрия Бураго, 2010. - 576 с.

8. Философская антропология: словарь / Под ред. Н. Хамитова. - 4-е издание, дополненное и переработанное. - К.: КНТ, 2017. - 472 с.

9. Фромм Э. Душа человека. Ее способность к добру и злу / Э. Фромм // Душа человека. - М.: Республика, 1992. - С. 13-108.

10. Фромм Э. Искусство любить / Э. Фромм // Душа человека. - М.: Республика, 1992. - C. 109-178.

11. Хамитов Н. Философия: бытие, человек, мир. От метафизики к метаантропологии. - 4-е издание, исправленное и дополненное / Н. Хамитов. - К.: КНТ, 2017. $-268 \mathrm{c}$.

12. Хамітов Н.В. Філософська антропологія: актуальні проблеми. Від теоретичного до практичного повороту. 2-е видання, виправлене і доповнене / $\mathrm{H}$. Хамитов. - К.: КНТ, 2018. - 394 с.

13. Хамітов Н. Воля до наукової новизни як умова неможливості плагіату /Н. Хамітов. // Вища освіта України. - № 2. - 2018. - С. 13-19.

14. Хамитов Н.В. Философско-антропологические эссе / Н. Хамитов. - К.: КНТ, 2018. $-284 \mathrm{c}$.

15. Хамитов Н.В. Искусство как разрешение противоречий жизни / Н. Хамитов. К.: КНT, 2018. -223 c.

16. Хамітов Н., Крилова С. Філософська освіта та наука в Україні: відповіді на нові виклики глобалізації XXI століття // Європейські педагогічні студії. - Вип. № 5-6. $-2015 .-$ C. $95-111$.

17. Хамітов Н., Крилова С. Філософський словник. Людина і світ. - 2-е видання, виправлене і доповнене / Н. Хамітов, С.Крилова. - К.: КНТ, 2018. - 394с.

18. Хамитов Н. Афоризмы свободы. Тайна гениальности. / Н. Хамитов. - К.: Афтар. - 2010. - 269 с.

19. Шелер М. Философское мировоззрение // Избранные произведения. - М.: Гнозис, 1994. - 480 с.

20. Khamitov N., Krylova S. Metaantropology as a philosophy of moral education in conditions of multicultural world. - Jinju, 2011. - P. 30-31.

\section{THE PHENOMENON OF PHILOSOPHICAL PUBLICISM AND THE SOCIOCULTURAL OPENNESS OF EDUCATION AND SCIENCE}

Summary. There are considered philosophical journalism and its social openness in academic education and science. The authors substantiate the thesis of the significant difference in the degree of openness of academic knowledge in an authoritarian and democratic society. In a totalitarian and authoritarian society, the logic and measure of public openness to academic knowledge is solved by a closed group of individuals. In a democratic society, academic openness is only possible in public debate, a living space of discourse that goes beyond the academic community with necessity. 
It is substantiated that, we have a true here-and-now-openness of academic knowledge in its educational and scientific dimensions, openness to the present, as a result of philosophical journalism.

Philosophical journalism is not just an accessible representation of the history of philosophy or the contemporary state of the directions of theoretical philosophy, it is a sphere of spiritual creativity, in which eternal worldview problems arise in a relevant social context. There are shown specificity of philosophical journalism concerning the related genres of essayist and journalism. Philosophical journalism is always humanistic in its depth, it stands on the guard of freedom of thought, awakens its criticality, protects against manipulation. The thesis about the consolidating nature of philosophical journalism in contemporary crisis societies, in particular in Ukraine, is substantiated. There are shown the tendency from true academism to publicism. True academicism immanently gravitates not so much to publicity but to journalism - the higher the academic status of an educator and scholar, the greater the degree of journalism he requires - the degree of openness of texts and speeches, the ability to speak in a accessible and interesting way, in order to be a social community. This journalism is philosophical, because it enables its media to integrate, generate and creatively defend ideas at various public venues.

The authors introduce the concept of "academic philosophical journalism"; as a result of such journalism, openness of education and science arises in a modern democratic society.

Keywords: publicity, journalism, philosophical journalism, academic philosophical journalism, philosophical essay, philosophical art, everyday human being, marginal human being, metaanthropology. 